\title{
Molecular cloning of equine transforming growth factor- $\beta 1$ reveals equine-specific amino acid substitutions in the mature peptide sequence
}

\author{
A J Nixon, B D Brower-Toland and L J Sandel1 ${ }^{1}$ \\ Comparative Orthopaedics Laboratory, College of Veterinary Medicine, Cornell University, Ithaca, \\ New York 14853, USA \\ ${ }^{1}$ Department of Orthopaedic Surgery, Washington University School of Medicine, St Louis, \\ Missouri 63110, USA \\ (Requests for offprints should be addressed to A J Nixon, Comparative Orthopaedics Laboratory, \\ C3-176 Veterinary Medical Center, Cornell University, Ithaca, New York 14853, USA; \\ Email: ajn1@cornell.edu)
}

\begin{abstract}
This study cloned and sequenced equine transforming growth factor (TGF)- $\beta 1$, yielding a unique nucleotide structure which predicted amino acid substitutions not seen in other mammalian species. The nucleotide sequence homology was $89 \%$ to bovine, $91 \%$ to man, $90 \%$ to ovine, and $86 \%$ to rat. Derived amino acid sequence comparison showed that the equine protein was unique, differing by two residues from man, cow, sheep, pig, and dog, and by three residues in the rat. Subsequent use of the cDNA clones to examine the expression of the TGF- $\beta 1$ gene in various tissues indicated predominant expression in adult spleen and kidney, with an age-related peak in cartilage expression at 12 months, followed by a decline as the animals matured. Northern blots showed that the predominant transcript sizes were 2.5 and $1.9 \mathrm{~kb}$. More
\end{abstract}

sensitive mRNA detection using PCR reaction showed peak cartilage TGF- $\beta$ mRNA levels in horses 0.7 and 1 year of age, with declining expression in older animals $(2 \cdot 5$ and $5 \cdot 5$ years of age).

In conclusion, although the primary nucleotide sequence of equine TGF- $\beta$ was relatively homologous to that of other species, the resulting amino acid sequence was unique to the horse, differing by two residues from the majority of mammalian sequences, where the peptide structure is identical. Expression of TGF- $\beta$ was particularly evident in spleen and kidney, and showed an age-related increase in expression in cartilage as the animals approached maturity and then a decline with progressive aging. Fournal of Molecular Endocrinology (2000) 24, 261-272

\section{INTRODUCTION}

Transforming growth factor (TGF)- $\beta 1$ is an important developmental peptide in cellular growth and differentiation (Hill 1992). Like many members of the transforming growth factor superfamily, it functions primarily as a controlling peptide in the formation of differentiated structures, beginning with embryonal organization, and extending to postnatal growth and tissue homeostasis (Iseki et al. 1995, Yamaguchi 1995). Although TGF- $\beta$ is produced locally by many tissues where it exerts paracrine and autocrine effects, extensive depot forms of latent TGF- $\beta$ exist that are predominantly derived from the circulation and stored as TGF- $\beta$ complexes. Mature TGF- $\beta 1$ is a 112 amino acid (AA), $25 \mathrm{kDa}$ homodimer, which exists as a double-chain polypeptide of two identical units conjoined by disulfide linkages. The mature molecule is folded and stabilized by interchain disulfide bridges between several of the nine cysteine residues. The structure of the latent molecule varies according to tissue source. Latent TGF- $\beta$ from cell cultures is a complex of the mature 112 AA TGF- $\beta$ and the precursor 'latency' glycoprotein, which becomes loosely reassociated to the dimer by non-covalent bonds. The structure becomes more complex in TGF- $\beta 1$ from platelets and some other cell lines, where an additional $125-190 \mathrm{kDa}$ 'modulating' or 'binding' glycoprotein 
is attached to the surface precursor glycopeptide. The possible role of these additional peptide structures after TGF- $\beta$ activation is largely unknown. The mature peptide circulates complexed to plasma proteins, predominantly $\alpha_{2}$-macroglobulin, to form inactive large molecular weight composites, which may be a scavenging system for active TGF- $\beta$ (Huang et al. 1988, Roberts \& Sporn 1990), although it could also be protecting TGF- $\beta$ from degradation, acting as a reservoir, or a system for sustained release (Massague 1990).

The 390 AA TGF- $\beta$ precursor peptide (pre-proTGF- $\beta$ ) consists of three portions: a signal peptide 23-29 AAs in length (depending on species) attached to the $\mathrm{NH}_{2}$-terminal, followed by the 249 AA $\mathrm{NH}_{2}$-terminal extension propeptide, and finally the 112 AA mature molecule (Sporn et al. 1986). The entire signal peptide is co-translationally cleaved, targeting TGF- $\beta$ to the secretory pathway (Perlman \& Halvorson 1983). The propeptide is then secreted from the cell and processed extracellularly to remove the amino-terminal propeptide (Massague 1987). The AA sequence of the processed peptide has been described to be identical between species where the sequence is known, with a single AA substitution in rodents.

The gene for TGF- $\beta$ extends over at least 100 kilobase (kb) pairs, and contains 7 exons, separated by six large non-coding intron sequences ranging in size from 1.9 to $40 \mathrm{~kb}$ (Derynck et al. 1987, van Obberghen-Schilling et al. 1987). Although there are long $5^{\prime}$ - and $3^{\prime}$-untranslated regions (UTR) in the TGF- $\beta 1$ mRNA, exon 1 still encodes the signal peptide and part of the amino-propeptide, exons 2, 3,4 and the $5^{\prime}$-portion of exon 5 code for the propeptide domain of the TGF- $\beta$ molecule, and the $3^{\prime}$-end of exon 5 along with exons 6 and and the $5^{\prime}$-portion of exon 7 code for the mature peptide. The remaining $3^{\prime}$-portion of exon 7 codes the $3^{\prime}$-untranslated sequence. Exons 4 and 5 can be deleted in an alternate splicing of the nascent RNA in man and pig which, at least in the pig, is described to result in a frame shift and a truncated unique amino-terminal to the mature TGF- $\beta$ molecule (Kondaiah et al. 1988). These two pools of mRNA arise from alternate splicing of exons 4 and 5 from the nascent RNA derived from the TGF- $\beta$ gene, resulting in deletion of a 227 base portion of the mRNA coding the amino-terminal propeptide region. Although the frequency of occurrence of the alternate splice form in pig is considerably less than the dominant splice form, where the exons are retained, the precise frequency and distribution of the alternate splice pattern are not well described (Kondaiah et al. 1988). No evidence for similar splicing patterns in other animal species has been defined, nor have the biological implications of this splice variant been extensively explored in the pig.

In the postnatal period, TGF- $\beta$ functions in homeostasis and connective tissue repair at many sites, including bone, skin, cartilage and muscle (Morales \& Roberts 1988, Tyler et al. 1989, Sandberg 1991). Body stores of TGF- $\beta$ are concentrated in bone, platelets, and the kidney (Assoian et al. 1983, Centrella et al. 1994, Dallas et al. 1995), which provide a ready pool to many sites of injury. In cartilage, TGF- $\beta$ is an important anabolic polypeptide growth factor, which may be activated from subchondral bone stores in acute cartilage injury and advanced osteoarthritis (Tyler et al. 1989, Sandberg 1991). The contribution of chondrocyte TGF- $\beta$ autocrine and paracrine actions to overall cartilage repair are not known, although the use of exogenous TGF- $\beta$ in cartilage repair has been described (Hunziker \& Rosenberg 1996). Many publications have described the extensive mitogenic effects of TGF- $\beta$ in cartilage explants and chondrocytes in culture and, to a lesser extent, some stimulus to matrix synthesis (Morales et al. 1990, Galera et al. 1992, Luyten et al. 1994, Fortier et al. 1997). These effects have been duplicated in vivo to a limited extent by the intra-articular application of exogenous TGF- $\beta$ (van Beuningen et al. 1994, Hulth et al. 1996); however, the induction of arthrofibrosis was a significant side-effect (Allen et al. 1990, Elford et al. 1992). Despite these side-effects and given its defined role in cartilage growth and development, it seems plausible that TGF- $\beta$ in some form may still play a vital role in adjunctive therapy for enhanced cartilage repair in acute or chronic joint disease. The attenuation of constitutive TGF- $\beta$ expression by exogenous TGF- $\beta$ application would lessen the impact of TGF- $\beta$ supplementation; however, previous studies suggest that TGF- $\beta$ is autoinductive (van Obberghen-Schilling et al. 1988, Rosier et al. 1989, Ballock et al. 1997). Additionally, TGF- $\beta$ driven autocrine or paracrine insulin-like growth factor-I (IGF-I) gene expression in articular chondrocytes has been described (Tsukazaki et al. 1994). This study describes the cDNA structure of equine TGF- $\beta 1$, including an extensive analysis of exon 4 and 5 -deleted substructures, and examines the expression of the TGF- $\beta$ gene in tissues, including articular cartilage, where it has known anabolic effects.

\section{MATERIALS AND METHODS}

\section{Animals and tissues}

Total RNA was isolated from equine liver, kidney, spleen, brain, platelets, cartilage, and tendon from 
horses 3·5-, 6-, 7-, and 12-months old. Additionally, RNA was isolated from cartilage, liver and kidney from 2.5- and 5.5-year-old horses. Primary chondrocyte cultures were established from cartilage obtained from the femoropatellar joints of an 8 -month-old and a 12-month-old horse. Chondrocytes were isolated from cartilage and cultured according to published methods (Nixon et al. 1992). Chondrocytes were cultured to confluence at 4 days without passage prior to isolation of RNA.

\section{RNA isolation}

Total RNA was isolated from frozen specimens pulverized in a freezer mill (Spexmill: Spex Industries, Edison, NJ, USA) and homogenized in a $4 \mathrm{M}$ guanidinium isothiocyanate solution containing $100 \mathrm{mM}$ Tris, $25 \mathrm{mM}$ EDTA, and $0.0625 \%$ 2-mercaptoethanol, in a modification of previous methods (Adams et al. 1992). The homogenate was centrifuged and extracted up to three times with saturated acid phenol and chloroform-isoamyl alcohol mixtures. Each extraction was centrifuged at $15000 \mathrm{~g}$ for $20 \mathrm{~min}$ at $4{ }^{\circ} \mathrm{C}$. The aqueous phase was removed each time and re-extracted with the phenol-chloroform mixture. The RNA was precipitated with equal volumes of isopropanol and precipitated by centrifugation at $25000 \mathrm{~g}$ for $30 \mathrm{~min}$. The pellet was redissolved in lysis buffer and $70 \%$ ethanol using a commercial nucleic acid spin column procedure (RNeasy kit: QIAGEN Inc., Chatsworth, CA, USA). The eluant RNA content from the spin column was quantified by u.v. spectrophotometry at $260 \mathrm{~nm}$, and RNA quality assessed from the ratio of absorbance at $260 \mathrm{~nm}$ and $280 \mathrm{~nm}$, and the appearance of ribosomal RNA bands on a $1 \%$ non-denaturing agarose gel. The RNA was stored at $-70{ }^{\circ} \mathrm{C}$.

\section{Reverse transcription-polymerase chain reaction}

The complete cDNA sequence encoding the TGF $-\beta$ prepropeptide was derived from a total of nine overlapping clones. At least eight other clones were produced in attempts to define an alternate splice form of TGF- $\beta$ due to exon 4 and 5 deletion. The 5'-terminus was sequenced using 5'-RACE techniques and nested primer sets. Primers for reverse transcription (R'T) and polymerase chain reaction (PCR) were 24-36 mer oligonucleotide sequences derived from homologous regions of known sequence data for human, ovine, bovine, porcine, and rodent TGF- $\beta$. Known equine TGF- $\beta$ sequence data were used for extending the $5^{\prime}$ and $3^{\prime}$-coding regions for the prepropeptide. All primers had integrated restriction enzyme sites for subsequent subcloning and the positions of the most important primers in cloning for the TGF- $\beta$ gene are illustrated in Fig. 1. Primer sequences are listed in Table 1 . Specific primers that spanned the exon 3-exon 6 junction and that primed outside exons 4 and 5 of the equine sequence were used in attempts to clone the alternate splice form.

$\mathrm{RT}$ of mRNA transcripts in total RNA of equine cartilage, kidney, or platelet origin was performed, using both specific TGF- $\beta$ primers and random primers. RT conditions included $2 \mu \mathrm{g}$ total RNA, $1 \mu \mathrm{M}$ primer, and 5 units avian myeloblastosis virus reverse transcriptase (cDNA Cycle Kit; Invitrogen Corp., San Diego, CA, USA), incubated at $42{ }^{\circ} \mathrm{C}$ for $60 \mathrm{~min}$. The RT product was used directly for PCR synthesis of a double-stranded DNA product. PCR was used to amplify the cDNA product from the respective RT reactions. Conditions for PCR included $0 \cdot 2 \mu \mathrm{M}$ specific upstream and downstream TGF- $\beta$ primers, $1.5 \mathrm{mM} \mathrm{MgCl}_{2}, 0.2 \mathrm{mM}$ dNTPs, PCR buffers, and 4 or $6 \mu \mathrm{l}$ RT product. Taq DNA polymerase (Promega Corp., Madison, WI, USA; 5 units) was added under hot start conditions in a PCR thermal cycler (Gene Amp 9600; Perkin Elmer, Foster City, CA, USA). PCR conditions included $95^{\circ} \mathrm{C}$ denaturation for $1 \mathrm{~min}, 55^{\circ} \mathrm{C}$ annealing for $1.5 \mathrm{~min}, 72^{\circ} \mathrm{C}$ extension for $2 \mathrm{~min}$, for a total of 30 cycles. Variations in the amplification strategy were necessitated by the rarity of the target message in starting RNA pools as well as the GC-rich character of the TGF- $\beta 1$ coding sequence. The resulting product was evaluated on a 1 or $2 \%$ non-denaturing agarose gel.

\section{Ligation to plasmid vector}

All cDNA inserts were prepared with restriction sites to facilitate subcloning into similar restriction sites of the polycloning region of $p \operatorname{Gem} 3 \mathrm{Zf}(+)$ (Promega Corp.). The cDNA inserts and plasmid were prepared by restriction enzyme digest prior to separation of the DNA on a $2 \%$ non-denaturing agarose gel. The relevant bands were excised and the DNA extracted using DNA affinity silica suspensions (QIAQuick Gel Extraction; QIAGEN Inc.). After quantitation on a $1 \%$ agarose gel, the cDNA insert and $\mathrm{pGem}$ vector were ligated using 60 or $120 \mathrm{ng}$ TGF- $\beta$ cDNA and $800 \mathrm{ng}$ pGem vector. Ligation was performed at $15{ }^{\circ} \mathrm{C}$ for $24 \mathrm{~h}$ using T4 DNA ligase (Promega Corp.). The ligation product was then evaluated on a $1 \%$ agarose gel. 


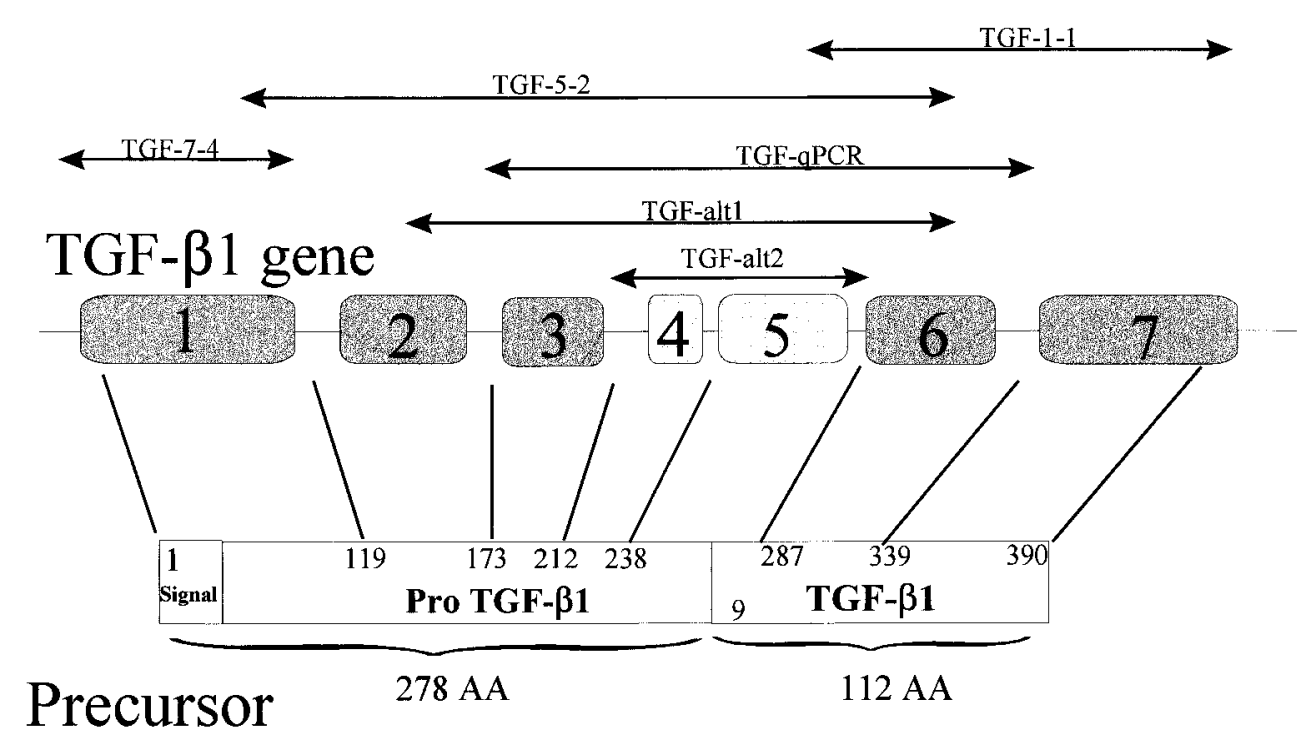

FIGURE 1. TGF- $\beta$ gene consisting of 7 exons (labeled 1-7) with intron sequence appearing as an interconnecting line. The translated protein is a 390 AA prepropeptide consisting of signal peptide, propeptide, and mature TGF- $\beta$ peptide. Three separate clones were developed by RT-PCR and sequenced to provide overlapping exon sequence data for the equine TGF- $\beta 1$ molecule. Primer regions of each clone are depicted by enlargements of each arrow.

\section{Transformation to DH5a}

Competent DH5a E. coli were aliquoted to chilled polypropylene tubes and $40-60 \mathrm{ng}$ of the pGem ligation reaction added per $100 \mu \mathrm{l}$ cells. The mixture was incubated on ice for $30 \mathrm{~min}$. The cells were then heat shocked at $42{ }^{\circ} \mathrm{C}$ for $45 \mathrm{~s}$, incubated on ice for a further $2 \mathrm{~min}$, and added to $800 \mu \mathrm{l}$ culture media at room temperature. The culture media was incubated at $37^{\circ} \mathrm{C}$ for $45 \mathrm{~min}$ and $100 \mu \mathrm{l}$ spread on fresh agar plates containing $100 \mu \mathrm{g} / \mathrm{ml}$ ampicillin and a surface layer of $\mathrm{x}$-gal and IPTG for color selection of transformed colonies. After overnight incubation at $37^{\circ} \mathrm{C}$, white colonies were selected for further propagation. The presence of the TGF- $\beta$ DNA insert in these colonies was confirmed by PCR of the supernatant following lysis and centrifugation. Colonies with confirmed inserts were selected for a 12-h propagation in $6 \mathrm{ml}$ Luria-Bertani media incubated at $37^{\circ} \mathrm{C}$. Isolation of the cloned plasmid from the $\mathrm{DH} 5 \alpha$ vector used a lysis procedure essentially as described by Birnbolm \& Dolly (see Maniatis et al. 1989), or using a lysis and DNA selective spin column procedure according to the manufacturer's protocol (QIAGEN Inc.). The resultant plasmid was evaluated for size and concentration by $1 \%$ agarose gel electrophoresis, and the restriction enzymes EcoR1 and BamH1 were used to excise the original DNA insert to confirm its size by comparison with 123 DNA ladder (Gibco-Life Technologies, Grand Island, NY, USA).

\section{Sequencing}

Each TGF- $\beta$ clone was sequenced using dyeterminator procedures on an ABS Autosequencer (Applied Biosystems Division, Perkin Elmer) and several ambiguous regions were verified by manual sequencing. Two individual colonies from each clone were sequenced in both forward and reverse directions to provide consensus data. Dye terminator sequencing was done according to the manufacturer's guidelines (Perkin Elmer). Aliquots $(1 \mu \mathrm{g})$ of DNA were mixed with $3 \cdot 2 \mathrm{pmol}$ T7 or SP6 DNA polymerase (Promega Corp.), dye terminator mix (Perkin Elmer), and $1 \mu \mathrm{l}$ Taq DNA polymerase (Promega Corp.), prior to PCR using a $96{ }^{\circ} \mathrm{C}-30 \mathrm{~s}$ denaturation, $50{ }^{\circ} \mathrm{C}-15 \mathrm{~s}$ annealing, and $60{ }^{\circ} \mathrm{C}-$ 3 min extension protocol for 25 cycles. The PCR product was then electrophoresed on an ABS370 autosequencer (Perkin Elmer) according to the manufacturer's directions. Manual sequencing on $6 \%$ acrylamide denaturing gels was done according to published methods (Maniatis et al. 1989). Sequence data from individual clones were aligned and compared with TGF- $\beta$ sequence from other 


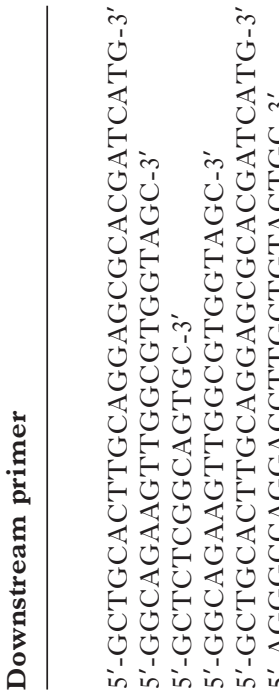

species using commercial software packages (Lasergene; DNASTAR Inc., Madison, WI, USA).

\section{Northern blot analysis}

TGF- $\beta$ mRNA presence and distribution in various tissues was detected on Northern blots probed with ${ }^{32} \mathrm{P}$-labeled TGF- $\beta$ cDNA inserts. Total RNA samples $(20 \mu \mathrm{g})$ from horse liver, kidney, spleen, brain, tendon, and chondrocyte cultures, and cartilages from normal femoropatellar joints of 3.5-, 6-, and 12-month-old immature horses were separated on a $1.5 \%$ agarose denaturing gel and transferred to nylon membranes by capillary blotting in SSPE as described (Maniatis et al. 1989). The nylon membranes were prehybridized at $55^{\circ} \mathrm{C}$ in a $5 \times \mathrm{SSPE}, 1 \cdot 0 \% \mathrm{SDS}, 20 \%$ formamide solution containing $100 \mu \mathrm{g} / \mathrm{ml}$ denatured salmon sperm DNA and Denhardt's solution. Probes for hybridization included a $713 \mathrm{bp}$ equine TGF- $\beta$ insert retrieved from the $\mathrm{pGem} 3 \mathrm{Zf}(+)$ plasmid, and a $680 \mathrm{~kb}$ bp elongation factor Tu (EFTu) insert (R Levine, Cornell University, Ithaca, NY, USA) retrieved from pBluescript (Promega Corp.) for use as a control probe to verify similar lane loadings as previously described (Levine et al. 1993). The DNA inserts $(25 \mathrm{ng})$ were radiolabeled with $\left[\alpha-{ }^{32} \mathrm{P}\right] \mathrm{dCTP}$ (New England Nuclear, Cambridge, MA, USA) using a random priming procedure with the Klenow fragment of DNA polymerase. Each radiolabeled probe $\left(10^{6}\right.$ c.p.m. $\left./ \mathrm{ml}\right)$ was added to the prehybridization mixture, and the membranes were hybridized at $50{ }^{\circ} \mathrm{C}$ for $18 \mathrm{~h}$. After rinsing in $2 \times \mathrm{SSPE} /$ $0.1 \% \mathrm{SDS}$ and $0.5 \times \mathrm{SSPE} / 0 \cdot 1 \% \mathrm{SDS}$ at $55^{\circ} \mathrm{C}$, the membranes were exposed to radiographic film (BioMax film; Eastman Kodak Co., Rochester, NY, USA) for 24-48 h using intensifying screens.

\section{Semi-quantitative RT-PCR for tissue expression of TGF- $\beta$}

Presence of TGF- $\beta$ mRNA in various tissues was assessed by PCR amplification reaction using specific TGF- $\beta$ primers to provide qualitative comparative data. More quantitative data were determined using a non-competitive RT-PCR protocol. Non-competitive quantitative PCR was performed essentially as described by $\mathrm{Re}$ et al. (1995) with the addition of EFTu primers to generate an internal control for sample message content. TGF- $\beta$ primers were designed using the equine sequence and the exon boundaries defined by Derynck et al. (1987) for the human TGF gene, to produce a $530 \mathrm{bp}$ product whose $5^{\prime}$ - and $3^{\prime}$-ends spanned the exon $2-3$ and exon 6-7 junctions respectively. This product was cloned directly from 
the primary amplification reaction using a cloning kit (TOPO TA; Invitrogen, Carlsbad, CA, USA). A standard curve was developed from amplification of known copy numbers of a TA TGF- $\beta$ plasmid. cDNAs were synthesized from $1 \mu \mathrm{g}$ of each sample tissue total RNA using oligo(dT) primer. After synthesis, RT reactions were diluted $1: 1$ with Tris/EDTA buffer. A volume containing 1/40th of each amount of synthesized cDNA was amplified in PCR reactions containing Taq polymerase, $1.5 \mathrm{mM}$ $\mathrm{MgCl}_{2}, 200 \mu \mathrm{M} \mathrm{dNTPs}, 0 \cdot 2 \mu \mathrm{M}$ each primer (TGF and EFTu). The thermal cycling profile was 36 cycles at $94{ }^{\circ} \mathrm{C} / 15 \mathrm{~s} ; 62{ }^{\circ} \mathrm{C} / 15 \mathrm{~s} ; 72{ }^{\circ} \mathrm{C} / 30 \mathrm{~s}$, with a 5 -min final extension at $72^{\circ} \mathrm{C}$. Samples and standards were amplified simultaneously for each assay. One fifth of each PCR reaction was analyzed by $1.5 \%$ Tris/acetate/EDTA agarose electrophoresis. Stained gels were photographed and images were scanned and analyzed to determine pixel intensity and copy number.

\section{RESULTS}

Three different TGF- $\beta$ clones were developed to provide overlapping exon sequence data for the equine TGF- $\beta 1$ prepropeptide. The 5 '-region was difficult to amplify and needed a kit specific for GC-rich regions (Advantage-GC kit: Clontech Laboratories, Palo Alto, CA, USA) to allow production of the TGF-7-4 clone. Analysis of PCR product using primers spanning the alternately spliced exon $4-5$ region of the equine TGF- $\beta$ gene did not result in the formation of more than one amplified cDNA band (Fig. 2). Sequence data representing the composite of all equine TGF- $\beta$ clones are presented in Fig. 3. The coding region for the prepro-TGF- $\beta$ extended from bases 15 to 1187, and consisted of the signal peptide (15-101), the pro-TGF- $\beta$ molecule (102-1187), and the mature TGF- $\beta$ region from 849 to 1187 . Nucleotide sequence similarities to other species varied from $91 \%$ to human, $90 \%$ for ovine, porcine and canine, to $89 \%$ for bovine, and $86 \%$ similarity to the rat. The cDNA sequence coding only the mature TGF- $\beta$ portion of the equine molecule was $93 \%$ and $96 \%$ homologous to bovine and human sequence data respectively.

The derived AA sequence of equine TGF- $\beta 1$ is presented in Fig. 4. The full TGF- $\beta 1$ prepropeptide contained 390 AAs. The AA sequence of the 112 AA mature equine TGF- $\beta$ differed by two residues from cow, sheep, pig, dog, and man. These species have AA substitutions at residues 286 and 360 , while the rat contains three different AA residues. The 29 AA signal peptide region of equine

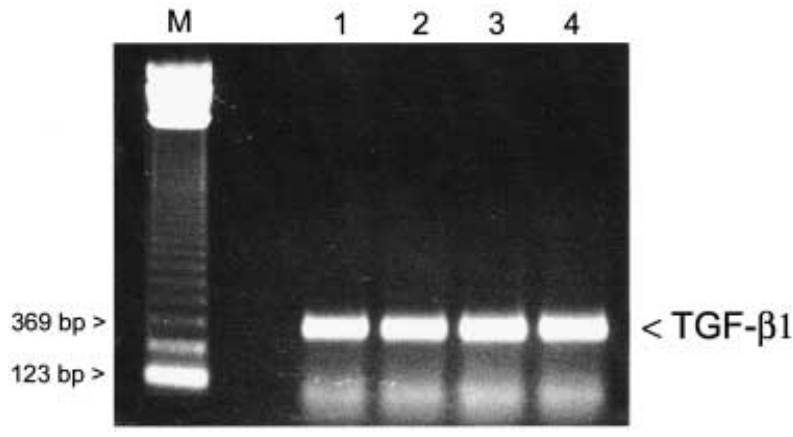

FIGURE 2. PCR product on $1 \%$ non-denaturing agarose gel showing a single cDNA product of approximately $208 \mathrm{bp}$ size. Primers for PCR were derived from TGF- $\beta$ nucleotide sequence at either end of the TGF- $\beta$-alt clone depicted in Fig. 1. Since these primers flank the alternately spliced exon 4 and 5 region, two separate PCR products of appropriate size would provide preliminary support for alternate splicing of the TGF- $\beta$ nascent RNA, which did not develop here. Size markers are derived from 123 DNA ladder.

TGF- $\beta 1$ was identical to that described for man and pig, but differed by one AA residue for the sheep, rat, and dog. The 249 AA TGF- $\beta$ amino-propeptide extension sequence showed significant species variability, with the sequence for man containing 34 substitutions $(13 \%)$, including an extra residue (AA 160) not described in animals, while the rat propeptide had 47 differing AAs (18\%).

\section{Northern blot analysis}

Two TGF- $\beta$ mRNA transcripts of different sizes were evident on Northern blots prepared from total RNA derived from liver, kidney, spleen, brain, tendon, cartilage, and chondrocytes in culture (Fig. 5). Estimated mRNA sizes were $2.5 \mathrm{~kb}$ and $1.9 \mathrm{~kb}$. The larger mRNA size $(2.5 \mathrm{~kb})$ predominated in all tissues. Message abundance was most apparent in samples from the spleen and kidney, with an increase in TGF- $\beta$ in cartilage samples of increasing maturity up to 1 -year old. Minimal expression could be found in liver, brain, and tendon.

\section{TGF- $\beta$ expression in tissues}

qPCR amplification of total RNA pools from organs, cartilage, and other connective tissues indicated abundant levels of TGF- $\beta$ in liver, kidney, skin, and cartilage from 1 -year-old horses, and an age-related decline in TGF- $\beta$ mRNA content in normal cartilage from animals older than 1 year (Fig. 6). 


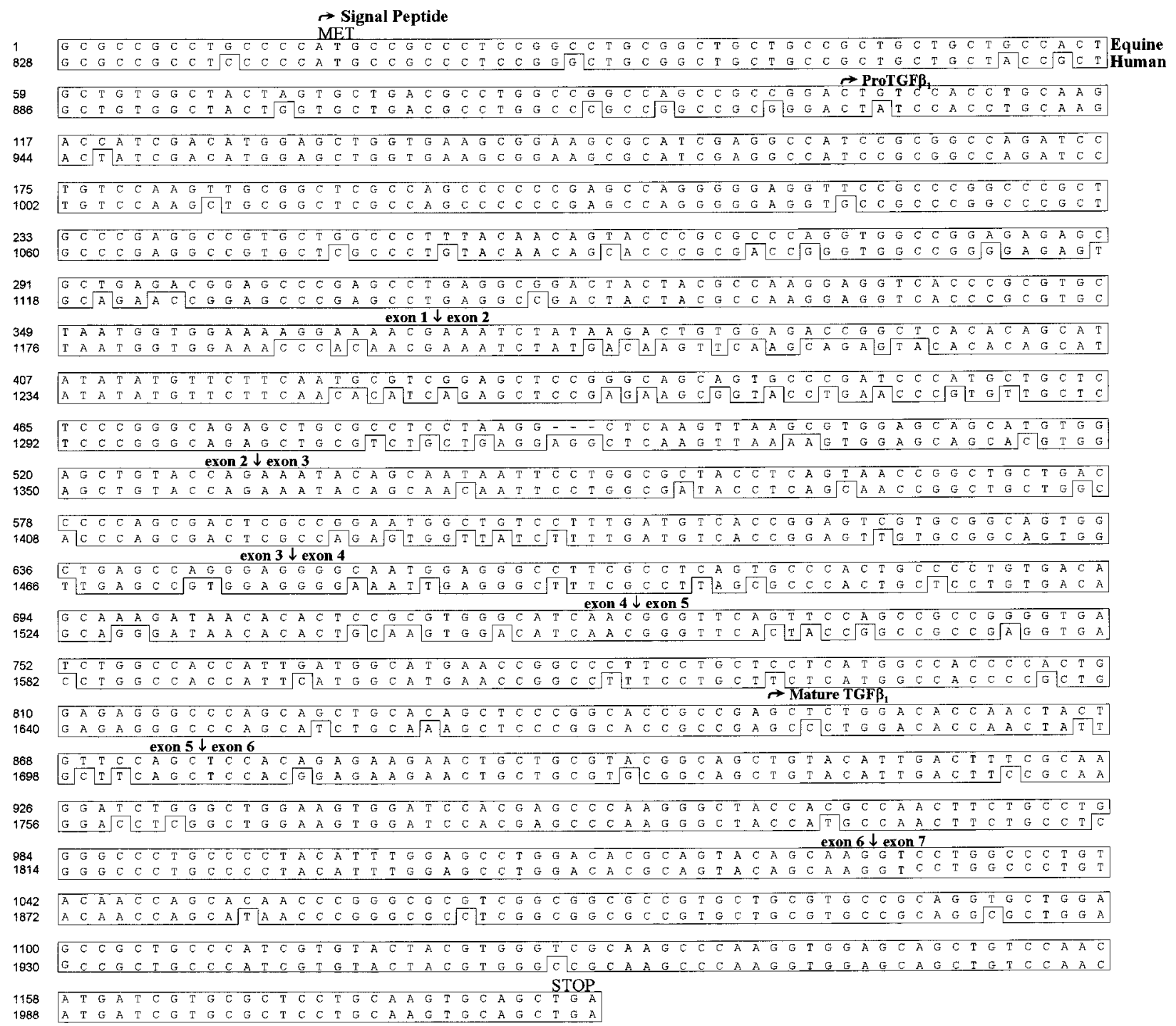

1988 A A T T G A A T

FIGURE 3. Nucleotide exon sequence data for equine TGF- $\beta 1$. Differences in the sequence for man are excluded from the boxing. Primers for amplification flanked the entire open reading frame and are not included here. Primers used to develop internal sequence were verified by overlapping clones. Exon boundaries are indicated and the major structural divisions of the predicted peptide are labeled. The translational start site (ATG) is labeled as a methionine residue (Met), and the stop codon (TGA) completes the listed nucleotide structure (Stop).

\section{DISCUSSION}

The primary nucleotide structure of equine TGF- $\beta$ was derived from cDNAs encoding the transcribed portion of the TGF- $\beta 1$ gene. This included portions of the $5^{\prime}$-UTR. The complete cDNA sequence to mRNA for the equine TGF- $\beta$ prepropeptide varied considerably from other species, although the sequence coding the mature TGF- $\beta$ molecule was more homologous to published sequences from other species (93-96\%

www.endocrinology.org identity). Several regions of equine TGF- $\beta$ sequence are published (Penha-Goncalves et al. 1997), or available in sequence databases (Genbank accession number X99438). However, interpretation of sequence features and data on expression in tissues are unavailable. Considerable species variation and differences in the equine nucleotide structure were evident in the mid-portion of the 5 '-propeptide region. This was reflected in AA mismatch by as much as $18 \%$ for the propeptide region of the rat when compared with the horse. In 
1

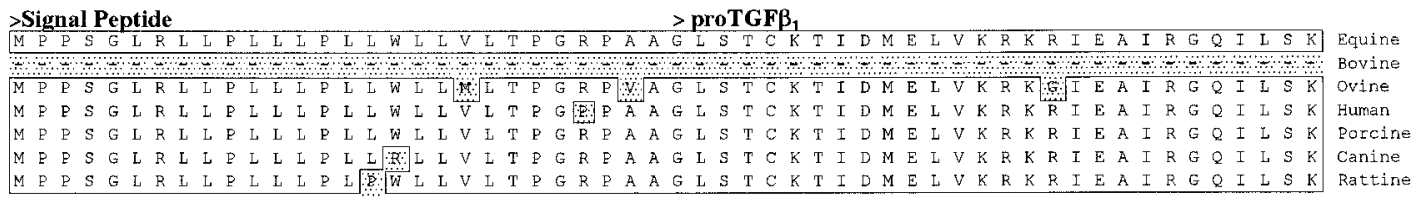

57

L R L A S E P S Q GEV P P G E I P E A V L A L Y N S T R A Q V A G E S A E T E P E P E A D

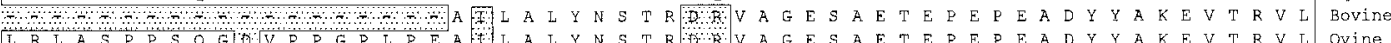

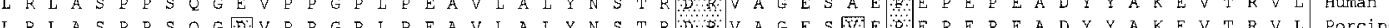
$L$ L L A S I R L L E S S P P S Q G G E V P P P

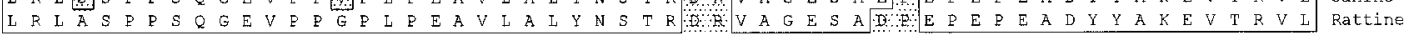

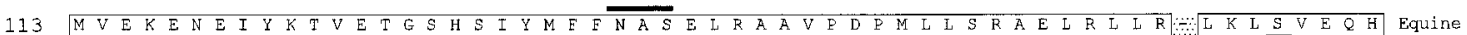

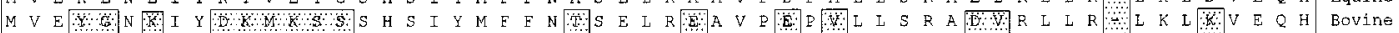

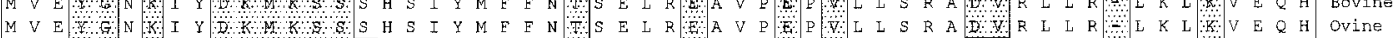

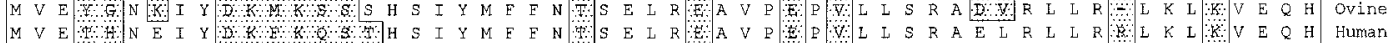

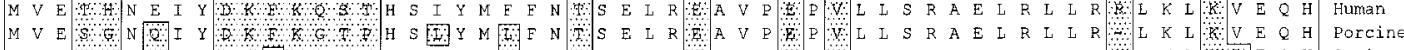
M V E N N N N W I

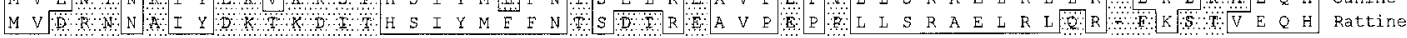

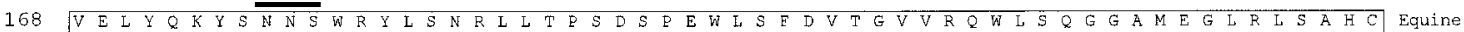

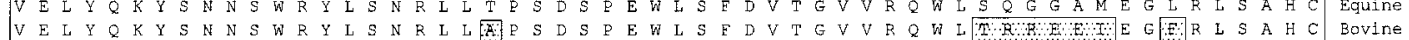

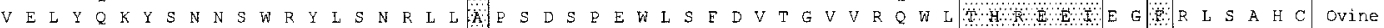

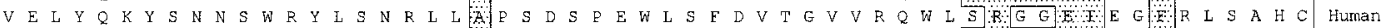

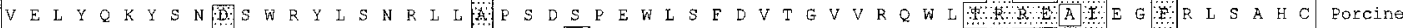
V E I Y Q

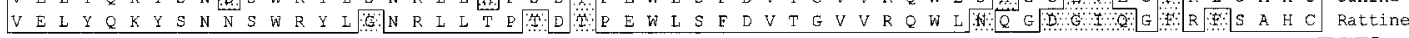

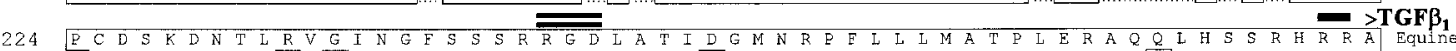

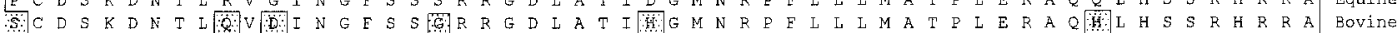

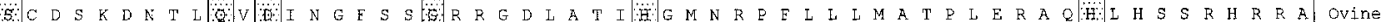

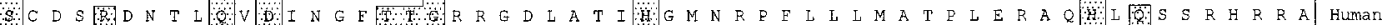
S. C D S

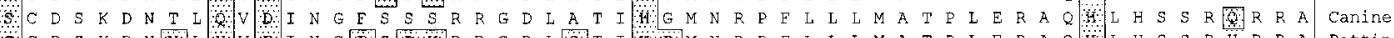

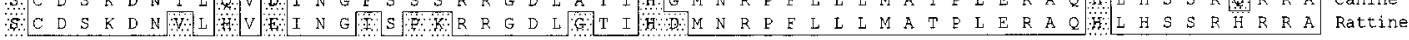

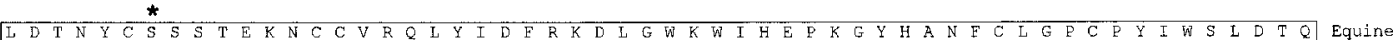

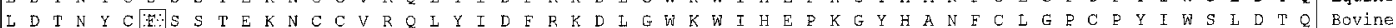

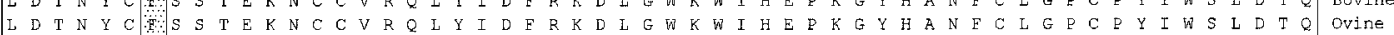
I $D$ T T N L D T $N$ N Y C C F L D T N Y C E S S S T E K N C C V R Q L Y I D F R K D L G W K W I H E

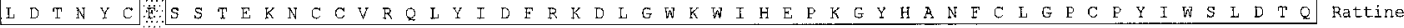

Y S K V L A L Y N Q H N E G A S A A B C C V P Q V L E F L P I V Y Y V G R K E K V E Q I S N M I V R S C K C S F Equine Y S K V V L A L Y Y N Q H N

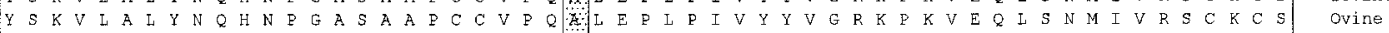

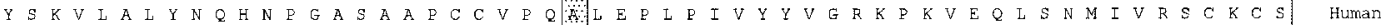

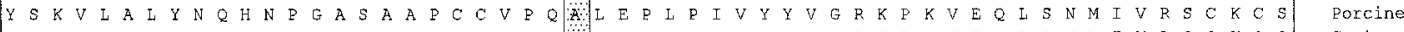
Y $S$ K V V L A L L Y N

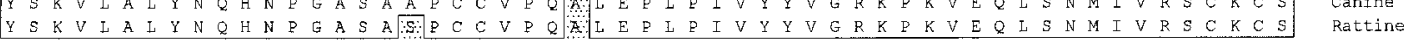

FIGURE 4. Derived AA sequence data for the equine pre-pro-TGF- $\beta 1$ molecule. Differences from other domestic species, rodents, and man are listed. Shaded areas represent residues that differ from the equine sequence. AAs within the mature TGF- $\beta 1$ molecule that are unique to the equine are indicated by asterisks. Three potential N-linked glycosylation sites are indicated by single overlining. The highly conserved integrin binding site (RGD), common to all TGF- $\beta$ members except TGF- $\beta 2$, is double overlined. The putative dipeptide proteolytic cleavage site (RR) is indicated by the heavier bar. The mature 112 AA TGF- $\beta 1$ peptide commences immediately beyond the cleavage site and is labeled (TGF- $\beta 1$ ).

contrast to these areas of difference, several areas of the propeptide region showed virtual identity to most other mammalian sequence. This profound sequence identity implies strong evolutionary pressure and suggests portions of the propeptide may have biological roles after TGF- $\beta$ cleavage. Further, several propeptide features conserved among the TGF- $\beta$ isoforms and between species for TGF- $\beta 1$ are present in equine TGF- $\beta 1$. These include three cysteine residues, the presence of three N-linked glycosylation sites, and the integrin cellular recognition site, RGD. The basic RHRR AA sequence, typical of the proteolytic processing site preceding the mature TGF- $\beta$ peptide, was also confirmed in the horse. This Arg-Arg sequence is nested within a hydrophilic region, suggesting that it would be susceptible to trypsin-like proteases. Other describe plasmin and cathepsin as possible activators of the latent form of TGF- $\beta$, supporting this observation (Roberts \& Sporn 1990).

The processed 112 AA equine TGF- $\beta 1$ was unique, with two AA substitutions compared with human, bovine, ovine, canine, and porcine species, contradicting popular opinion that TGF- $\beta$ s from 

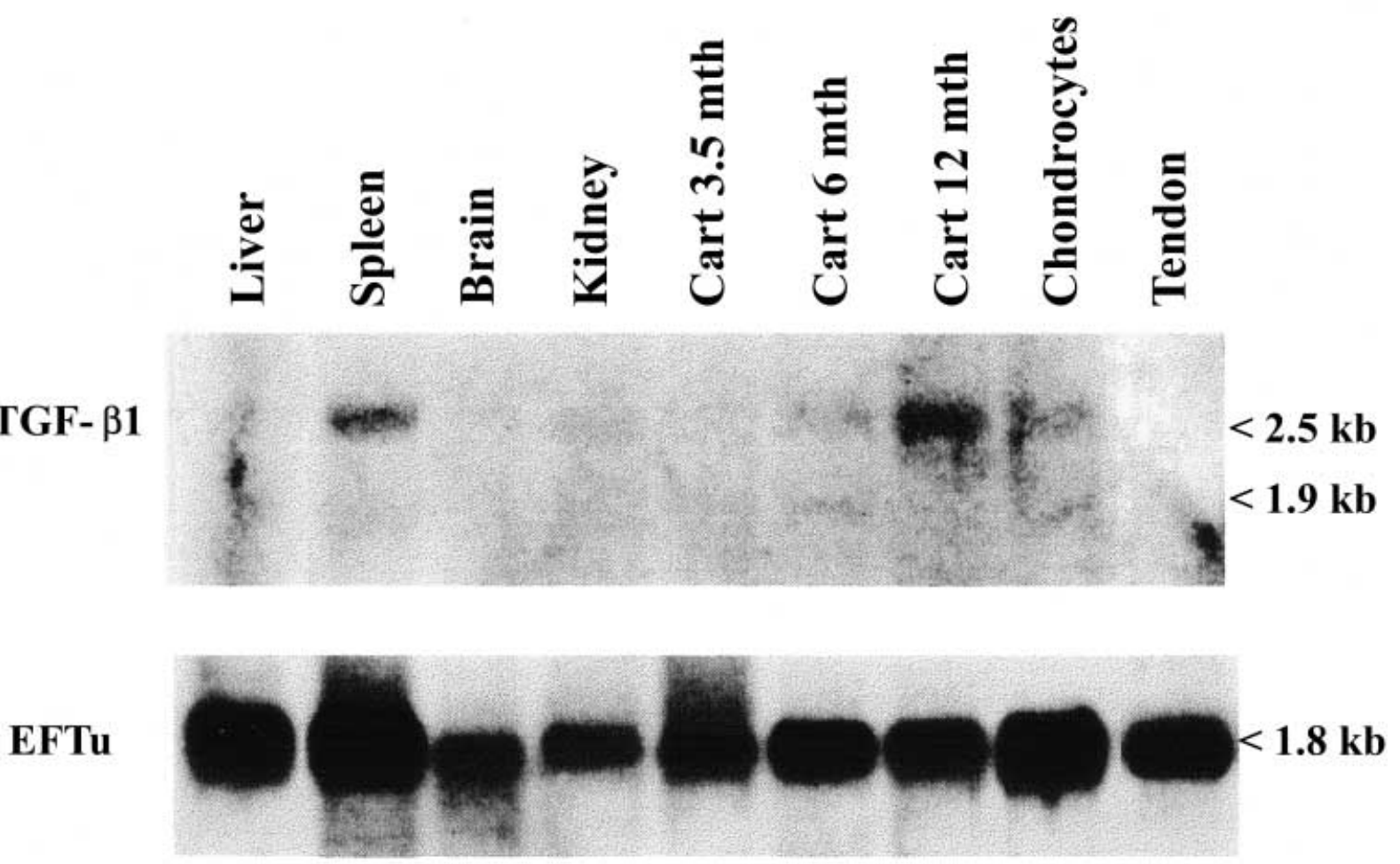

FIGURE 5. Northern blot analysis of mRNA obtained from liver, spleen, brain, kidney, and tendon from horses 6- to 8-months old, cartilage (Cart) from horses 3.5- to 12 -months old, and chondrocytes derived from horses 8 and 12-months old, probed using a $713 \mathrm{bp}{ }^{32} \mathrm{P}$-labeled cDNA insert derived from the TGF- $\beta 1$ clone. Each lane was loaded with $20 \mu \mathrm{g}$ total RNA. TGF- $\beta 1$ expression is most prominent in spleen, kidney (corrected for uneven RNA loading), and cartilage derived from a 12 -month-old animal. The $2 \cdot 5 \mathrm{~kb}$ band predominates over the $1.9 \mathrm{~kb}$ band in all tissues examined. The ${ }^{32} \mathrm{P}$-labeled EFTu cDNA probe $(680 \mathrm{bp})$ was used to define loading differences in total RNA for each lane.

most domestic animals have an identical peptide sequence, and setting aside the horse from this well-conserved pattern. Substitution of Phe278 with Ser278 and Ala360 with Val360 are unlikely to represent major functional residue substitutions. Despite these differences, the mature equine TGF- $\beta 1$ molecule contained the highly conserved nine cysteine residues found in all TGF- $\beta$ isoforms, which separates them from other members of the TGF- $\beta$ superfamily. There are no data on which of these cysteine residues are involved in the interchain disulfide bridges complexing the two monomers in the TGF- $\beta$ homodimer (Derynck et al. 1985). Finally, the conserved carboxy-terminal residue sequence Cys-Lys-CysSer-COOH (CKCS-COOH) common to all TGF- $\beta$ s other than TGF- $\beta 5$ was present in the equine sequence.

Cloning of the $5^{\prime}$ - and $3^{\prime}$-UTRs was complicated by the extensive GC-rich sequences in these extensions (Derynck et al. 1985, van Obberghen-
Schilling et al. 1987). Portions of the TGF- $\beta$ sequence from man show as much as $80 \% \mathrm{GC}$ prevalence in the $5^{\prime}$-UTR. Use of $5^{\prime}$-RACE procedures yielded cDNA product which was further used in nested primer PCR to yield portions of the $5^{\prime}$-region. The $3^{\prime}$-region was not characterized. Others have failed to clone and derive sequence from the $3^{\prime}$-UTR of the TGF- $\beta$ molecule due to the 75 base purine sequence immediately following the stop codon (Derynck et al. 1985).

The equine nucleotide sequence coding the TGF- $\beta 1$ signal peptide was relatively homologous to other species, including regions coding a hydrophobic core 16 AAs (Leu8-Pro23) and extending most likely to include a total of 29 AAs. The exact processing site for the signal peptide is conjectural, with the Gly-24 and Gly-29 being likely candidate positions. Previous reports describe one of these two sites as likely processing points (Derynck et al. 1985, 1986, Penha-Goncalves et al. 


\section{TGF- $\beta$ qPCR Standard Curve}
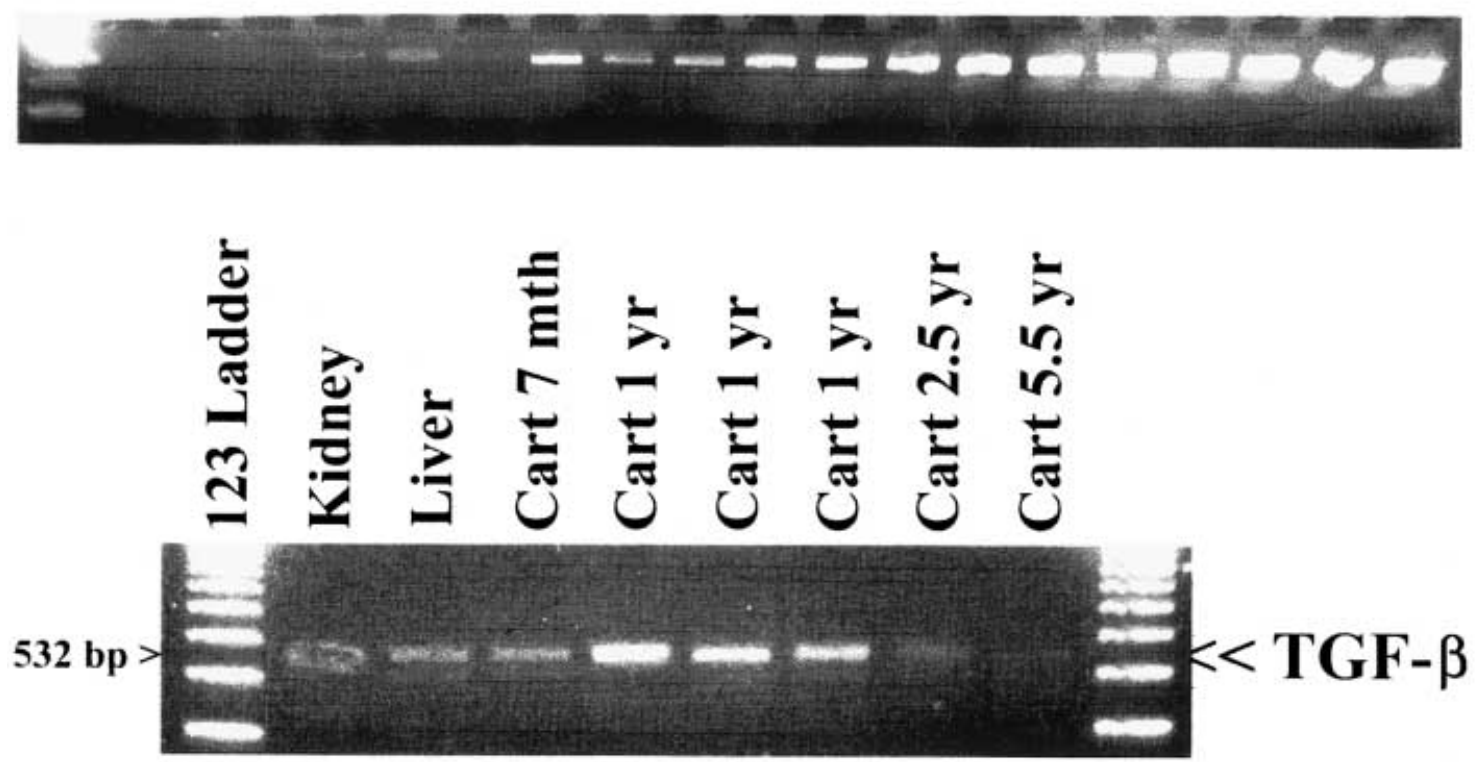

FIGURE 6. Expression of TGF- $\beta$ mRNA in tissues. Standard curve (top) was derived from non-competitive qPCR using increasing cDNA template numbers. The gel (bottom) shows PCR product from equine cartilage (Cart) and organ total RNA amplified using equine specific primers spanning exon 2-3 and exon $6-7$. TGF- $\beta$ mRNA is evident in RNA from kidney, liver, and 7-month-old foal cartilage, is predominantly expressed in cartilage from 1 -year-old horses, and is expressed to a lesser extent in $2 \cdot 5$ - and $5 \cdot 5$-year-old cartilage.

1997), although typical signal peptides are 20-23 residues in length (Perlman \& Halvorson 1983). A basic peptide region is typical of many secreted proteins, where the signal peptide allows translocation across the endoplasmic reticulum. The presence of a signal sequence is common to all but TGF- $\beta 4$, which has no discernible signal peptide (Jakowlew et al. 1988).

An alternative splicing pattern of the aminoterminal of the TGF- $\beta$ RNA transcript seen in the pig (Kondaiah et al. 1988) could not be confirmed in the equine TGF- $\beta 1$ precursor, despite considerable effort to identify its presence. The prevalent mRNA form has exons 4 and 5 retained in the mRNA molecule, resulting in the classic 390 AA TGF- $\beta 1$ precursor. The alternately spliced TGF- $\beta$ contains a 75 AA deletion from the TGF- $\beta$ propeptide and the amino-terminus of the mature TGF- $\beta$ structure. Of more significance is the introduction of a frame shift and the activation of an in-frame stop codon resulting in a truncated $45 \mathrm{AA}$ residue in place of the 112 AA TGF- $\beta$ peptide (Kondaiah et al. 1988). Debate surrounds the biological role of the two different propeptide amino-terminal domains derived from this alternately spliced 5'-translated region (Kondaiah et al. 1988), particularly since the amino-terminus of the new product is structurally different. Additionally, the Arg-Arg site for cleavage of the mature TGF- $\beta$ molecule in post-translational processing is destroyed, replaced by several other sites further toward the aminoterminus (Kondaiah et al. 1988). The resultant 45 AA mature peptide has not been identified and characterized to our knowledge.

Two predominant transcript pools, 2.5 and $1.9 \mathrm{kbp}$ in size, were apparent on Northern blot analysis. This is consistent with previous reports of two major transcription start sites (Kim et al. 1989a). A promoter upstream of the $5^{\prime}$-start site and a second between the two start sites lends support to the two predominant transcript pools being a consistent feature (Kim et al. 1989b). Both promoters contain transcriptional enhancer elements that respond to phorbol esters as well as TGF- $\beta$ peptide in an autoinductory pattern (Kim et al. 1990). No evidence of larger TGF- $\beta$ transcripts was evident on Northern blots, contrary to findings in the pig (Kondaiah et al. 1988). 
Expression of TGF- $\beta$ mRNA was evident in many tissues in the horse, including parenchymatous organs such as the spleen and kidney. These tissues were derived from relatively young animals, whereas previous studies suggest adult kidney and spleen may have reduced TGF- $\beta$ expression (Derynck et al. 1985, van Obberghen-Schilling et al. 1987). Variable levels of TGF- $\beta$ were also apparent in cartilage from horses of various ages. Northern blot analysis showed increasing message levels in cartilage derived from foals approaching maturity, followed by a decline in older horses. Major transcriptional activity was evident in the spleen, and moderate expression was present in the kidney. Previous studies describe the ubiquitous distribution of TGF- $\beta 1$, and this study supports those findings (Thompson et al. 1989, Roberts \& Sporn 1990). The distribution of TGF- $\beta$ transcriptional activity in cartilage is not as well defined. Message expression of TGF- $\beta$ was evident in cartilage RNA samples derived from horses of various ages. The autocrine and paracrine activity of TGF- $\beta$ in cartilage has been described (Rosier et al. 1989, Ballock et al. 1997), although circulating TGF- $\beta$ is presumed to contribute to cartilage development and homeostasis to some extent (Thompson et al. 1989, Morales 1991). This study reveals an age-related TGF- $\beta$ expression profile in cartilage. Concurrent decline in TGF- $\beta$ message expression in aging animals and changes in TGF- $\beta$ receptor activity may be linked to the overall diminished response of mature chondrocytes to TGF- $\beta$ ligand.

\section{ACKNOWLEDGEMENT}

This study was funded through the Harry M Zweig Memorial Fund for Equine Research.

\section{REFERENCES}

Adams ME, Huang DQ, Yao LY \& Sandell LJ 1992 Extraction and isolation of mRNA from adult articular cartilage. Analytical Biochemistry 202 89-95.

Allen JB, Manthey CL, Hand AR, Ohura K, Ellingsworth L \& Wahl SM 1990 Rapid onset synovial inflammation and hyperplasia induced by transforming growth factor B. Fournal of Experimental Medicine 171 231-247.

Assoian RK, Komoriya A, Meyers CA, Miller DM \& Sporn MB 1983 Transforming growth factor- $\beta$ in human platelets: identification of a major storage site, purification, and characterization. Fournal of Biological Chemistry 258 7155-7160.

Ballock RT, Heydemann A, Izumi T \& Reddi AH 1997 Regulation of the expression of the type-II collagen gene in periosteum-derived cells by three members of the transforming growth factor- $\beta$ superfamily. Fournal of Orthopaedic Research 15 463-467. van Beuningen HM, van der Kraan PM, Arntz OJ \& van den Berg WB 1994 Transforming growth factor- $\beta 1$ stimulates articular chondrocyte proteoglycan synthesis and induces osteophyte formation in the murine knee joint. Laboratory Investigation $71279-290$.

Centrella M, Horowitz MC, Wozney JM \& McCarthy TL 1994 Transforming growth factor- $\beta$ gene family members and bone. Endocrine Reviews 15 27-39.

Dallas SL, Miyazono K, Skerry TM, Mundy GR \& Bonewald LF 1995 Dual role for the latent transforming growth factor- $\beta$ binding protein in storage of latent TGF- $\beta$ in the extracellular matrix and as a structural matrix protein. Fournal of Cell Biology 131 539-549.

Derynck R, Jarrett JA, Chen EY, Eaton DH, Bell JR, Assoian RK, Roberts AB, Sporn MB \& Goeddel DV 1985 Human tranforming growth factor-beta complementary DNA sequence and expression in normal and transformed cell lines. Nature 316 701-705.

Derynck R, Jarrett JA, Chen EY \& Goeddel DV 1986 The murine transforming growth factor- $\beta$ precursor. Fournal of Biological Chemistry 261 4377-4379.

Derynck R, Rhee L, Chen EY \& van Tilburg A 1987 Intron-exon structure of human transforming growth factor- $\beta$ precursor gene. Nucleic Acids Research 15 $3188-3189$

Elford PR, Graeber M, Ohtsu H, Aeberhard M, Legendre B, Wishart WL \& MacKenzie AR 1992 Induction of swelling, synovial hyperplasia and cartilage proteoglycan loss upon intra-articular injection of transforming growth factor $\beta-2$ in the rabbit. Cytokine 4 232-238.

Fortier LA, Nixon AJ, Mohammed HO \& Lust G 1997 Altered biological activity of equine chondrocytes cultured in a three-dimensional fibrin matrix and supplemented with transforming growth factor $\beta 1$. American Fournal of Veterinary Research 58 66-70.

Galera P, Redini F, Vivien D, Bonaventure J, Penfornis H, Loyau G \& Pujol J-P 1992 Effect of transforming growth factor- $\beta 1$ (TGF- $\beta 1$ ) on matrix synthesis by monolayer cultures of rabbit articular chondrocytes during the dedifferentiation process. Experimental Cell Research 200 379-392.

Hill DJ 1992 Peptide growth factor interactions in embryonic and fetal growth. Hormone Research 38 197-202.

Huang SS, O'Grady P \& Huang JS 1988 Human transforming growth factor- $\beta$ :alpha2-macroglobulin complex is a latent form of transforming growth factor-B. Fournal of Biological Chemistry 263 1535-1541.

Hulth A, Johnell O, Miyazono K, Lindberg L, Heinegard D \& Heldin C-H 1996 Effect of transforming growth factor- $\beta$ and platelet-derived growth factor-BB on articular cartilage in rats. Fournal of Orthopaedic Research $\mathbf{1 4}$ 547-553.

Hunziker EB \& Rosenberg LC 1996 Repair of partial-thickness defects in articular cartilage: cell recruitment from the synovial membrane. Fournal of Bone and Foint Surgery 78-A 721-733.

Iseki S, Osumi-Yamashita N, Miyazono K, Franzen P, Ichijo H, Ohtani H, Hayashi Y \& Eto K 1995 Localization of transforming growth factor-beta type I and type II receptors in mouse development. Experimental Cell Research 219 339-347.

Jakowlew SB, Dillard PJ, Sporn MB \& Roberts AB 1988 Complementary deoxyribonucleic acid cloning of a messenger ribonucleic acid encoding transforming growth factor $\beta 4$ from chicken embryo chondrocytes. Molecular Endocrinology 2 1186-1195.

Kim S-J, Glick A, Sporn MB \& Roberts AB 1989a Characterization of the promoter region of the human 
transforming growth factor- $\beta 1$ gene. Fournal of Biological Chemistry 264 402-408.

Kim S-J, Jeang K-T, Glick AB, Sporn MB \& Roberts AB $1989 b$ Promoter sequences of the human transforming growth factor- $\beta 1$ gene responsive to transforming growth factor- $\beta 1$ autoinduction. Fournal of Biological Chemistry 264 7041-7045.

Kim S-J, Angel P, Lafyatis R, Hattori K, Kim KY, Sporn MB, Karin M \& Roberts A 1990 Autoinduction of transforming growth factor $\beta 1$ is mediated by the AP-1 complex. Molecular and Cellular Biology 10 1492-1497.

Kondaiah P, van Obberghen-Schilling E, Ludwig RL, Dhar R, Sporn MB \& Roberts AB 1988 cDNA cloning of porcine transforming growth factor- $\beta 1$ mRNAs. Fournal of Biological Chemistry 263 18313-18317.

Levine RA, Sendy M, Guo L \& Holzschu D 1993 Elongation factor $\mathrm{Tu}$ as a control gene for mRNA analysis of lung development and other differentiation and growth-regulated systems. Nucleic Acids Research 214426.

Luyten FP, Chen P, Paralkar V \& Reddi AH 1994

Recombinant bone morphogenetic protein-4, transforming growth factor $\beta 1$, and activin $A$ enhance the cartilage phenotype of articular chondrocytes in vitro. Experimental Cell Research 210 224-229.

Maniatis T, Fritsch EF \& Sambrook J 1989 Molecular Cloning: A Laboratory Manual, edn 2. New York: Cold Spring Harbor Laboratory.

Massague J 1987 The TGF- $\beta$ family of growth and differentiation factors. Cell $49437-438$.

Massague J 1990 The transforming growth factor-B family. Annual Review of Cell Biology 6 597-641.

Morales TI 1991 Transforming growth factor-beta 1 stimulates synthesis of proteoglycan aggregates in calf articular cartilage organ cultures. Achives of Biochemistry and Biophysics 286 99-106.

Morales TI \& Roberts AB 1988 Transforming growth factor $\beta$ regulates the metabolism of proteoglycans in bovine cartilage organ cultures. Fournal of Biological Chemistry 263 12828-12831.

Morales TI, Joyce ME, Sobel ME, Danielpour D \& Roberts AB 1990 Transforming growth factor- $\beta$ in calf articular cartilage organ cultures: synthesis and distribution. Achives of Biochemistry and Biophysics 288 397-405.

Nixon AJ, Lust G \& Vernier-Singer M 1992 Isolation, propagation and cryopreservation of equine articular chondrocytes. American Fournal of Veterinary Research $\mathbf{5 3}$ 2364-2370.

van Obberghen-Schilling E, Kondaiah P, Ludwig R, Sporn MB \& Baker CC 1987 Complementary deoxyribonucleic acid cloning of bovine transforming growth factor- $\beta 1$. Molecular Endocrinology 1 693-698. van Obberghen-Schilling E, Roche NS, Flanders KC, Sporn MB \& Roberts AB 1988 Transforming growth factor beta 1 positively regulates its own expression in normal and transformed cells. Fournal of Biological Chemistry 263 7741-7746.

Penha-Goncalves MN, Onions DE \& Nicolson L 1997 Cloning and sequencing of equine transforming growth factor-beta 1 cDNA. DNA Sequence 7 375-378.

Perlman D \& Halvorson HO 1983 A putative signal peptidase recognition site and sequence in eukaryotic and prokaryotic signal peptides. Fournal of Molecular Biology 167 391-409.

Re P, Valhmu WB, Vostrejs M, Howell DS, Fischer SG \& Ratcliffe A 1995 Quantitative polymerase chain reaction assay for aggrecan and link protein gene expression in cartilage. Analytical Biochemistry 225 356-360.

Roberts A \& Sporn M 1990 The transforming growth factor betas. In Peptide Growth Factors and their Receptors I, edn 1, pp 419-472. Eds M Sporn \& A Roberts. New York: Springer-Verlag.

Rosier RN, O’Keefe RJ, Crabb ID \& Puzas JE 1989 Transforming growth factor beta: an autocrine regulator of chondrocytes. Connective Tissue Research 20 295-301.

Sandberg MM 1991 Matrix in cartilage and bone development: current views on the function and regulation of major organic components. Annals of Medicine 23 207-217.

Sporn MB, Roberts AB, Wakefield LM \& Assoian RK 1986 Transforming growth factor- $\beta$ : biological function and chemical structure. Science 233 532-534.

Thompson NL, Flanders KC, Smith JM, Ellingsworth LR, Roberts AB \& Sporn MB 1989 Expression of transforming growth factor- $\beta 1$ in specific cells and tissues of adult and neonatal mice. Fournal of Cell Biology 108 661-669.

Tsukazaki T, Usa T, Matsumoto T, Enomoto H, Ohtsuru A, Namba H, Iwasaki K \& Yamashita S 1994 Effect of transforming growth factor- $\beta$ on the insulin-like growth factor-1 autocrine/paracrine axis in cultured rat articular chondrocytes. Experimental Cell Research 215 9-16.

Tyler JA, Bird JLE, Giller T \& Benton HP 1989 Cytokines, growth factors and cartilage repair. In Osteoarthritis. Current Research and Prospects for Pharmacological Intervention, edn 1, pp 144-153. Eds RGG Russel \& PA Dieppe. Sheffield: IBC Technical Services Ltd.

Yamaguchi A 1995 Regulation of differentiation pathway of skeletal mesenchymal cells in cell lines by transforming growth factor- $\beta$ superfamily. Seminars in Cell Biology 6 165-173.

REVISED MANUSCRIPT RECEIVED 12 October 1999 